Žarko Vranjanac ${ }^{1}$

Dragan Spasić ${ }^{2}$

Scientific Institution/University of Niš,

Faculty of Occupational Safety in Niš, Serbia
SCIENTIFIC REVIEW ARTICLE

DOI:10.5937/ekonomika1702105V

Received: March, 21, 2017

Accepted: April, 03, 2017

\title{
WASTE MANAGEMENT WORKFORCE COST ANALYSIS IN SERBIA FROM 2009 TO $2015^{3}$
}

\begin{abstract}
Waste management entails business expenses during the performance of waste management activities. The bulk of these expenses comprise workforce costs, costs of amortization, energy, tools and equipment, etc. The aim of this paper is to analyze the workforce cost in waste management in Serbia from 2009 to 2015 using statistical data analysis. The results show a constant increase in the total gross and net waste management workforce costs. The gross waste management workforce cost increased by $70.5 \%$ during the analyzed period, while the net cost in the same category increased by as much as $72.75 \%$.
\end{abstract}

Key words: workforce cost, waste management, Serbia

JEL classification: Q5

\section{АНАЛИЗА ТРОШКОВА РАДНЕ СНАГЕ У ДЕЛАТНОСТИ УПРАВЉАЊА ОТПАДОМ У СРБИЈИ У ПЕРИОДУ ОД 2009. ДО 2015. ГОДИНЕ}

\begin{abstract}
Апстракт
Управљање отпадом проузрокује пословне расходе који настају у току рада, односно обављања делатности. Највећи део ових трошкова представљају трошкови радне снаге, амортизаиије, енергије, средстава и опреме за рад и др. Циљ овог рада је сагледавање трошкова радне снаге за управљање отпадом у Републици Србији у периоду од 2009. до 2015. године применом методе статистичке анализе података. Резултати показују константно повећане укупних бруто и нето трошкова радне снаге за управљање отпадом. У анализираном периоду, бруто трошкови радне снаге за управљање отпадом, повећали су се за 70,5\%, док су се нето трошкови радне снаге за управљање отпадом повећали за чак $72,75 \%$.
\end{abstract}

Кључне речи: трошкови радне снаге, управљање отпадом, Србија

\footnotetext{
${ }^{1}$ zarko.vranjanac@znrfak.ni.ac.rs

${ }^{2}$ dragan.spasic@znrfak.ni.ac.rs

${ }^{3}$ Acknowledgements: The paper is a part of the research done within the projects No. III-43014 funded by the Serbian Ministry of Science.
} 


\section{Introduction}

Waste management is directly involved in environmental protection, but it also has a high socio-economic significance. That is why good waste management practice is often called sustainable waste management. "In market economies, waste is presented as a potential resource, an ever-growing secondary raw material with a positive exchange value" (Vujić \& Brunner, 2009, p. 44). Thus, the real value of waste is determined. Nevertheless, "proper waste management from the moment of generation, through collection, transport, treatment, all the way to final disposal prevents diseases and epidemics, minimizes the possibility of injury, protects the environment, and provides room for more productive activities, which collectively constitutes the hidden value of waste" (Vranjanac, 2015, p. 67). Certain costs are incurred during all of the said stages of waste management, but the aim of this paper is to analyze the costs of waste management workforce in Serbia. "Entire families in developing countries such as Serbia make their living from collecting and selling secondary raw materials" (Brunner \& Fellner, 2007, p. 234). Yet, "this is not a systematic approach, since the hygiene requirements are much more demanding, which is observable through indicators and standards" (Pejčić, Vranjanac, Bakota, Namura, 2015, pp. 82-89).

\section{Waste Management Activity}

In the Republic of Serbia, activities are classified according to the:

- Law on the Classification of Activities ("Official Gazette of the Republic of Serbia", No. 104/09),

- Act on the Classification of Activities ("Official Gazette of the Republic of Serbia", No. 54/10), and

- Act on the Methodology for Classifying Classification Units According to Activity Classification ("Official Gazette of the Republic of Serbia", No. $54 / 10)$.

According to the Act on the Classification of Activities, waste management comprises:

- waste collection,

- waste treatment and disposal, and

- reuse of materials.

Collection of non-hazardous waste comprises:

- collection of non-hazardous solid from local territory, such as collection of municipal and commercial waste into mobile waste containers, which can yield a combination of reusable materials,

- collection of recyclable materials,

- waste collection from public surfaces,

- construction waste collection,

- collection and removal of debris such as twigs or gravel,

- textile waste collection,

- activities at transfer stations for non-hazardous waste. 
Collection of hazardous waste comprises:

- collection of solids and non-solids, e.g. explosive, oxidizing, flammable, toxic, irritating, carcinogenic, corrosive, infectious, and other substances and agents hazardous to human health and the environment,

- identification, processing, packaging, and labelling of waste for transport,

- collection of hazardous waste, such as: used motor oils, biohazardous waste, nuclear waste, used batteries, and

- $\quad$ activities at transfer stations for hazardous waste.

Waste treatment and disposal involves disposal and pre-disposal treatment for different waste types and in different ways, such as organic waste treatment for disposal, treatment and disposal of dead animals and other contaminated waste; treatment and disposal of hospital radioactive waste, waste unloading on the ground or into water, burial or ploughing in of the remains; disposal of used goods such as refrigerators in order to eliminate harmful waste; disposal of waste formed by incineration or combustion. This has the added benefit of obtaining energy through incineration. "Treatment and disposal of non-hazardous waste involves disposal and treatment prior to the disposal of solid and non-hazardous non-solid waste" (Theisen, Vigil, Tchobanoglous, 2012, p. 212):

- operation of non-hazardous waste landfills,

- disposal of non-hazardous waste by incineration or other methods, with or without further use of electric or steam energy, compost, fuel substitutes, biogas, ash, or other products, and

- treatment of organic waste for disposal.

"Treatment and disposal of hazardous waste involves disposal and pre-disposal treatment of solid and non-solid hazardous waste, including waste that is explosive, oxidizing, flammable, toxic, irritating, carcinogenic, corrosive, and infectious, and other substances and agents hazardous to human health and the environment" (Inglezakis \& Moustakas, 2015, 310). It comprises:

- operation of hazardous waste treatment facility,

- treatment and disposal of dead animals and other contaminated waste,

- incineration of hazardous waste,

- disposal of used goods (e.g. refrigerators), from which harmful materials are subsequently removed,

- treatment, disposal, and storage of radioactive nuclear waste including: treatment and disposal of hospital radioactive waste, encapsulation, preparation, or other types of nuclear waste treatment for storage purposes.

Reuse of materials involves:

- $\quad$ wreck dismantling and

- reuse of sorted materials.

Wreck dismantling involves the dismantling of any type of wreck (cars, ships, computers, TV sets, and other devices) for reuse. Reuse of sorted materials involves the processing of metal and non-metal waste, scrap, and remains into secondary raw materials, usually through physical or chemical transformation processes. It also involves reuse of materials from waste flows in the form of: 
1) separation and sorting of reusable materials from non-hazardous waste flows or

2) separation and sorting of reusable mixed waste, such as paper, plastics, used cans and metals into different categories.

\section{Waste management personnel}

According to the Law on Waste Management ("Official Gazette of the Republic of Serbia", No. 36/09), waste management is a public interest activity, involving the implementation of prescribed measures for waste handling within collection, storage, treatment, and disposal stages, including supervision of these activities and maintenance of waste management facilities after closure. "The process of waste management requires a specific number of qualified employees, from engineers, who deal with public utility activities and who are specialized in this field, to waste management technicians and operators, who perform tasks associated with waste collection, treatment, and disposal" (Vranjanac, 2015, p. 78). The number of employees involved in the removal of refuse, litter, and other waste in Serbia from 2002 to 2007 is shown in Table 1 and Figure 1.

Table 1: Number of employees involved in the removal of refuse, litter, and other waste in Serbia from 2002 to 2007

(Source: Statistical Yearbook of Serbia, 2003-2008)

\begin{tabular}{|l|l|l|}
\hline Year & $\begin{array}{l}\text { Number of } \\
\text { employees }\end{array}$ & Index \\
\hline 2002 & 10,816 & 100.00 \\
\hline 2003 & 11,388 & 105.29 \\
\hline 2004 & 11,669 & 108.16 \\
\hline 2005 & 12,153 & 112.36 \\
\hline 2006 & 12,388 & 114.53 \\
\hline 2007 & 12,596 & 116.45 \\
\hline
\end{tabular}

Based on these data, it can be concluded that the number of employees in waste removal increased annually. Throughout the period, the number of employees increased by $16.45 \%$, from 10,816 in 2002 to 12,569 in 2007 .

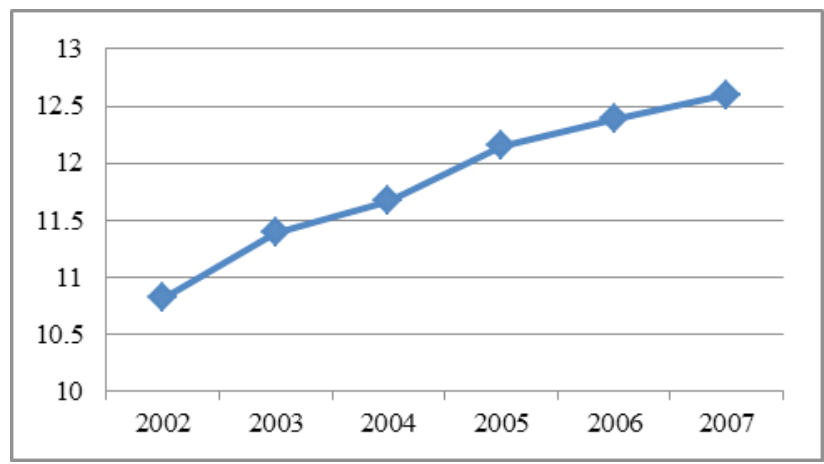

Figure 1: Number of employees involved in the removal of refuse, litter, and other waste in Serbia from 2002 to 2007 (in thousands) 
Since the activity removal of refuse, litter, and other waste was transformed into waste collection, treatment, and disposal in 2008, the number of employees for the newly-named activity in Serbia from 2008 to 2015 is shown in Table 2 and Figure 2.

Table 2: Number of employees involved in waste collection, treatment, and disposal in Serbia from 2008 to 2015

(Source: Statistical Yearbook of Serbia, 2010-2016)

\begin{tabular}{|l|l|l|}
\hline Year & Number of employees & Index \\
\hline 2008 & 14,030 & 100.00 \\
\hline 2009 & 14,505 & 103.39 \\
\hline 2010 & 14,285 & 101.82 \\
\hline 2011 & 14,370 & 102.42 \\
\hline 2012 & 14,615 & 104.16 \\
\hline 2013 & 15,786 & 112.52 \\
\hline 2014 & 15,867 & 113.09 \\
\hline 2015 & 18,695 & 133.25 \\
\hline
\end{tabular}

The data reveal that the number of employees in the analyzed eight-year period increased by $33.25 \%$, from 14,030 in 2008 to 18,695 in 2015 .

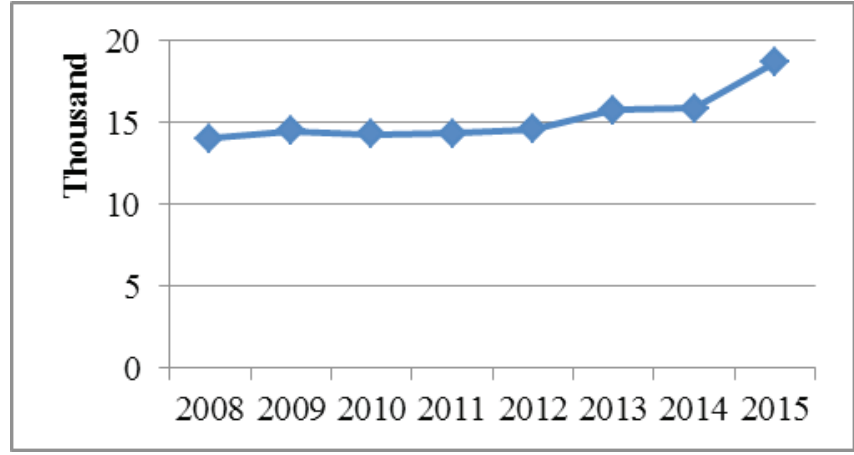

Figure 2: Number of employees involved in waste collection, treatment, and disposal in Serbia from 2008 to 2015 (in thousands)

\section{Calculation of waste management workforce cost}

The cost of the workforce hired for waste management in Serbia is expressed through their gross or net income. "The following formula is used for calculating the workforce cost expressed through gross income earned $\left(\mathrm{TRS}_{\mathrm{bz}}\right)$ )" (Spasić, 2003, p. 108):

$$
\mathrm{TRS}_{\mathrm{bz}}=\mathrm{Z} \times \mathrm{PBZ}
$$

where:

$\mathrm{Z}$ - number of employees and

PBZ - average gross income. 
"The following formula is used for calculating the workforce cost expressed through net income earned $\left(\right.$ TRS $\left._{\mathrm{nz}}\right)$ " (Spasić, 2003, p. 108):

where:

$$
\mathrm{TRS}_{\mathrm{nz}}=\mathrm{Z} \times \mathrm{PNZ}
$$

$\mathrm{Z}$ - number of employees and

PNZ - average net income.

\section{Results and discussion}

The data on the number of employees, average gross and net incomes, and workforce cost for waste management in Serbia from 2009 to 2015 are shown in Table 3 and Figure 3.

Table 3: Number of employees, average gross and net incomes, and workforce cost for waste management in Serbia from 2009 to 2015 (in dinars)

(Source: Statistical Yearbook of Serbia, 2010-2016)

\begin{tabular}{|l|l|l|l|l|l|}
\hline Year & $\begin{array}{l}\text { Number of } \\
\text { employees }\end{array}$ & $\begin{array}{l}\text { Avg. gross income } \\
\text { per employee }\end{array}$ & $\begin{array}{l}\text { Avg. net income } \\
\text { per employee }\end{array}$ & $\begin{array}{l}\text { Gross } \\
\text { workforce cost }\end{array}$ & $\begin{array}{l}\text { Net workforce } \\
\text { cost }\end{array}$ \\
\hline 2009 & 14,505 & 40,642 & 29,126 & $589,512.21$ & $422,472.63$ \\
\hline 2010 & 14,285 & 42,882 & 30,813 & $612,569.37$ & $440,163.70$ \\
\hline 2011 & 14,370 & 46,988 & 33,906 & $675,217.56$ & $487,229.22$ \\
\hline 2012 & 14,615 & 50,806 & 36,601 & $742,529.69$ & $534,923.61$ \\
\hline 2013 & 15,786 & 52,825 & 38,178 & $833,895.45$ & $602,677.91$ \\
\hline 2014 & 15,867 & 54,283 & 39,292 & $861,308.36$ & $623,446.16$ \\
\hline 2015 & 18,695 & 53,761 & 39,038 & $1,005,062.89$ & $729,815.41$ \\
\hline Total & 108,123 & - & - & $5,320,094.64$ & $3,840,728.64$ \\
\hline $\begin{array}{l}\text { Annual } \\
\text { average }\end{array}$ & 15,446 & $48,883.86$ & $35,279.14$ & $760,013.52$ & $548,675.52$ \\
\hline
\end{tabular}

The total gross workforce cost for waste management from 2009 to 2015 was $5,320,094.64$ dinars, whereas the total net workforce cost for the same field was $3,840,728.64$ dinars. These costs were incurred over the seven-year period by 108,123 employees, i.e. 15,446 employees per year.

The average gross income in waste management from 2009 to 2015 was $48,883.86$ dinars per employee, whereas the net income was 35,279.14 dinars per employee. The average gross annual income in waste management in Serbia was 760,013.52 dinars and the average net annual income was 548,675.52 dinars.

During the analyzed period, the gross workforce cost increased by $415,550.68$ dinars. Similarly, the net workforce cost increased by $308,342.78$ dinars. According to these data, the cost of hired waste management workforce in Serbia increased significantly over the analyzed period. The results show a constant increase in the total gross and net waste management workforce costs. It can be stated that they are growing from year to year without decrease. 


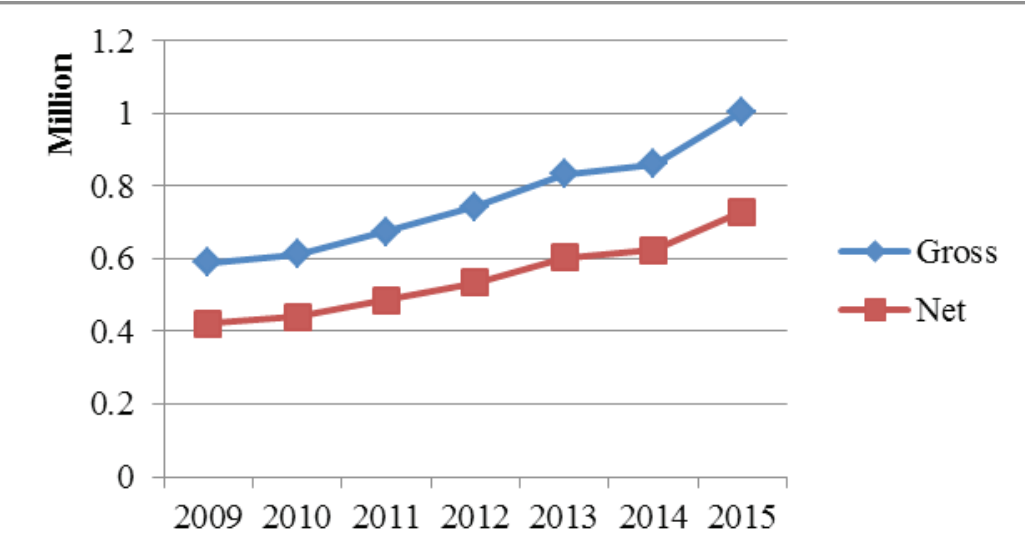

Figure 3: Gross and net waste management workforce cost in Serbia from 2009 to 2015 (in million dinars)

\section{Conclusion}

In order to avoid the negative impact of waste on the environment and human health, waste has to be managed. Waste management activity in Serbia is of particular importance for environmental protection, while it represents a developing field from an economic perspective. This is confirmed by the data analyzed in this paper, pertaining to workforce costs for waste management in Serbia from 2009 to 2015.

The waste management workforce comprises engineers, technicians, operators, and administrative and support staff, whose work incurs certain expenses. In this paper, workforce costs were calculated as a product of the number of employees and their average gross or net received income.

Ever since the activity removal of refuse, litter, and other waste was transformed into waste collection, treatment, and disposal in 2008, the number of employees over the analyzed seven-year period increased by $28.29 \%$, from 14,505 in 2009 to 18,695 in 2015.

The gross workforce cost of waste management increased by $70.5 \%$, from $589,512.21$ dinars in 2009 to 1,005,062.89 dinars in 2015. The net workforce cost increased by as much as $72.75 \%$, from $422,472.63$ dinars in 2009 to $729,815.41$ dinars in 2015. The difference between the gross and the net received incomes over the analyzed period amounts to $1,479,366.00$ dinars, which is the amount of money from waste management that went into the state budget.

According to these data, it was to be expected that the workforce cost would only increase each year, so the amount of money going into the budget of the Republic of Serbia would also increase. In addition to these economic benefits, hiring more workers in waste management implies a more favourable attitude towards the environment and people's health and wellbeing, which in turn contributes to the implementation of sustainable development goals. 


\section{References}

Brunner P. \& Fellner J. (2007). Setting priorities for waste in developing countries, Waste Management \& Research, Vol. 25, 234-240.

Inglezakis V. \& Moustakas K. (2015). Household hazardous waste management: A review, Journal of Environmental Management, Vol. 150, 310-321.

Pejčić D., Vranjanac Ž., Bakota M., Namura Al M. (2015). Povrede na radu u delatnosti upravljanja otpadom [Occupational Injuries in Waste Management], Paper presented at the conference Unapređenje sistema zaštite na radu, Tara, Serbia.

Spasić, D. (2003). Economics of Occupational Safety (Ekonomika zaštite na radu), Grafika Galeb, Niš, Serbia.

Statistical Yearbook of Serbia (2002-2016), Republic Institute for Statistics in Belgrade, Belgrade, Serbia.

Theisen H., Vigil S. \& Tchobanoglous G. (2012). Integrated solid waste management, Engineering Principles and Management Issues, McGraw-Hill Inc., 212-225.

Act on the Classification of Activities, "Official Gazette of the Republic of Serbia", No. br. $54 / 10$

Act on the Methodology for Classifying Classification Units According to Activity Classification, "Official Gazette of the Republic of Serbia", No. 54/10

Vranjanac Ž. \& Spasić D. (2016). Economic Effects of Collection and Primary Recycling of Packaging Waste from Hygiene and Cleaning Products in Serbia, Paper presented at the $6^{\text {th }}$ International Symposium on Environmental and Flow Management - EMFM 2016, Bor, Serbia.

Vranjanac, Ž. (2015). Economic-Environmental Impact of Household Care Products on the Environment (Ekonomsko-ekološki uticaj otpada od higijenskih sredstava na životnu sredinu), MSc thesis, Faculty of Occupational Safety in Nis, Nis, Serbia.

Vujić G. \& Brunner P. (2009). Sustainable Waste Management (Održivo upravljanje otpadom), Faculty of Technical Science, Novi Sad, Serbia.

Law on the Classification of Activities, "Official Gazette of the Republic of Serbia", No. 104/09

Law on Waste Management, "Official Gazette of the Republic of Serbia”, No. 36/09 